\title{
REVIEW
}

\section{Nucleic acid targeting: towards personalized therapy for head and neck cancer}

\author{
SM Parsel ${ }^{1}$, JR Grandis ${ }^{2}$ and SM Thomas Th $^{1,3,4}$
}

In light of a detailed characterization of genetic aberrations in cancer, nucleic acid targeting represents an attractive therapeutic approach with significant translational potential. Head and neck squamous cell carcinoma (HNSCC) is a leading cause of cancer deaths worldwide with stagnant 5-year survival rates. Advances in conventional treatment have done little to improve survival and combined chemoradiation is associated with significant adverse effects. Recent reports have characterized the genetic alterations in HNSCC and demonstrated that mutations confer resistance to conventional and molecular targeted therapies. The ability to use specific nucleic acid sequences to inhibit cancer-associated genes including non-druggable targets facilitates personalized medicine approaches with less adverse effects. Additionally, advances in drug delivery mechanisms have increased the transfection efficiency aiding in greater therapeutic responses. Given these advances, the stage has been set to translate the information garnered from genomic studies into personalized treatment strategies. Genes involved in the tumor protein 53 and epidermal growth factor receptor pathways have been extensively investigated and many promising preclinical studies have shown tumor inhibition through genetic modulation. We, and others, have demonstrated that targeting oncogene expression with gene therapy approaches is feasible in patients. Other methods such as RNA interference have proven to be effective and are potential candidates for clinical studies. This review summarizes the major advances in sequence-specific gene modulation in the preclinical setting and in clinical trials in head and neck cancer patients.

Oncogene (2016) 35, 3217-3226; doi:10.1038/onc.2015.424; published online 23 November 2015

\section{INTRODUCTION}

Head and neck squamous cell carcinoma (HNSCC) is a leading cause of morbidity and mortality worldwide and is primarily associated with tobacco and alcohol use. ${ }^{1}$ Owing to late clinical presentation and advanced stage, HNSCC leads to over 300000 deaths annually. Most patients require extensive, multidisciplinary treatment. However, even with aggressive treatment, the 5-year survival rate in the United States is only around $40 \%$ primarily due to the lack of effective therapeutic options for advanced-staged cancers. $^{2}$

In patients with locally advanced disease, relapse is common despite early therapeutic intervention. In these patients, prognosis is poor and conventional treatment yields only $30-40 \%$ response rates with a median survival between 6 and 9 months. ${ }^{3}$ Traditional chemotherapy has low tumor specificity leading to significant adverse effects in patients. Further, a wide array of gene aberrations in HNSCC are implicated in therapeutic failure to conventional therapy. ${ }^{4}$ While some mutations are etiologic, others confer sensitivity or resistance to chemotherapy. ${ }^{5-7}$

Expression of the variant III form of epidermal growth factor receptor (EGFR vIII) confers resistance to EGFR inhibitors and may explain the modest clinical response with these agents. ${ }^{8-10}$ Conversely, nearly one-third of HNSCC tumors harbor mutations in PI3KCA gene. ${ }^{11}$ The oncogenic PIK3CA (E542K) mutation confers exquisite sensitivity to PI3K pathway inhibitor BEZ-325. ${ }^{12}$ Given the heterogeneity in mutations, it would be difficult to develop small molecules or antibodies that specifically target each oncogenic mutation. ${ }^{11,13,14}$ In this scenario, the use of targeted nucleic acid therapy to mitigate expression of mutated genes with high sequence specificity would facilitate personalized cancer therapy and combat treatment failures. In this manuscript, we discuss advances in gene delivery systems, and preclinical and clinical studies using nucleic acid targeted therapy for HNSCC.

\section{GENE DELIVERY SYSTEMS}

Direct intratumoral administration of therapeutic nucleic acids for proof-of-concept studies is feasible in easily accessible sites such as the oral cavity. However, difficulty in accessing deep-seated tumors, low transfection efficiency, and susceptibility to nuclease degradation are major limitations with injection of naked DNA or RNA. $^{15}$ In order to facilitate systemic delivery and improve transfection efficiency, significant advances have occurred in vector development including liposomes, nanoparticles, and viral vectors (Figure 1). Liposome complexes protect nucleic acids from degradation and improve uptake in cells. A spherical lipid bilayer encapsulating the nucleic acid cargo fuses with the plasma membrane of cells, releasing the contents into the cytoplasm. In vitro studies show a transfection efficacy of up to $70 \%$; however, the presence of serum components can decrease this by $35-45 \% .{ }^{16}$ Despite the increase in efficiency, hematologic toxicity, hepatotoxicity, and innate immune responses have been associated with systemic therapy. ${ }^{17-19}$ In order to reduce toxicity and facilitate tumor specificity, next-generation liposomes carry

\footnotetext{
${ }^{1}$ Department of Otolaryngology, University of Kansas Medical Center, Kansas City, KS, USA; ${ }^{2}$ Department of Otolaryngology, University of Pittsburgh, Pittsburgh, PA, USA; ${ }^{3}$ Department of Cancer Biology, University of Kansas Medical Center, Kansas City, KS, USA and ${ }^{4}$ Department of Anatomy and Cell Biology, University of Kansas Medical Center, Kansas City, KS, USA. Correspondence: Dr SM Thomas, University of Kansas Medical Center, 3901 Rainbow Boulevard, 3020A Wahl Hall East, Kansas City, KS 66160, USA. E-mail: sthomas7@kumc.edu 


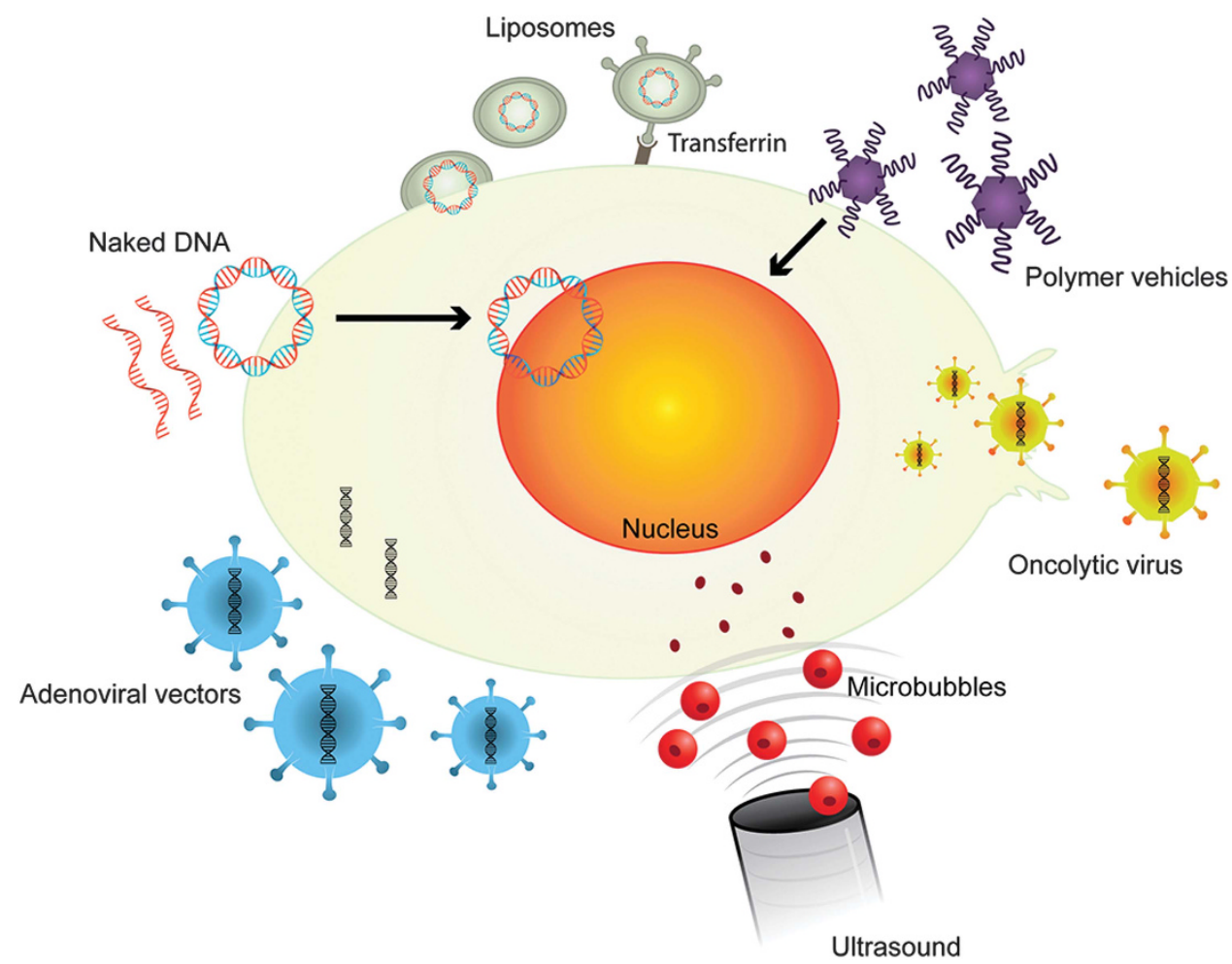

Figure 1. Summary of the delivery vectors primarily tested for nucleic acid therapy in HNSCC. Naked DNA in the form of plasmids or oligonucleotides can freely diffuse across the plasma membrane and may enter the nucleus for expression. Microbubbles carrying nucleic acids ruptured at the tumor site by ultrasound release nucleic acids cargo that diffuses into tumor cells. Liposomes with or without targeted peptides fuse with the plasma membrane and deliver cargo into the cell. Polymer vehicles diffuse across the plasma membrane and release the payload into the nucleus or cytoplasm. Viral vectors can efficiently deliver exogenous nucleic acids into tumor cells. Oncolytic viruses specifically replicate and lyse target tumor cells.

tumor-targeted peptides in the lipid bilayer. For instance, liposomes conjugated to the transferrin ligand have a higher affinity for HNSCC cells with upregulated transferrin receptors than non-malignant cells. In vitro results suggest an increase in transfection efficiency from 10 to $50 \%$ when using transferrin ligand attachments. ${ }^{20}$ Alternatively, the use of antitransferrin receptor single-chain antibody on the surface of cationic liposomes can increase specific uptake in tumor cells on systemic administration. ${ }^{21}$ The major challenge that persists with liposomes is hepatotoxicity upon clearance from circulation.

In an effort to decrease toxicity and increase transfection efficiency, other methods of gene delivery have been developed. Synthetic polymer complexes can diffuse across the plasma membrane or enter cells through endocytosis. Nucleotides dissociate from the polymer and exert their action within the cytoplasm or the nucleus. Common polymers used in HNSCC include polyethylenimine and glucosylated polyethylenimines. ${ }^{22-24}$ A challenge to the widespread use of these agents is the formation of complexes with blood components due to the high cationic charge. ${ }^{25}$ Conjugation with hydrophilic polymers reduces this positive charge, increasing bioavailability. In vitro gene transfection efficiency can reach up to $47 \%$ while retaining in vivo antitumor efficacy. ${ }^{26}$ Another novel mechanism for delivery involves systemically administered, ultrasound-guided microbubbles targeting HNSCC tumors. Vigorous mixing of aqueous solutions of lipid and nucleic acid generates microbubbles with a lipid shell and perfluorobutane gas interior. The average diameter of the microbubbles is $1-8 \mu \mathrm{m}$. Intravenously administered microbubbles are visualized using ultrasound imaging. As they perfuse the tumor, destruction of microbubbles with highfrequency ultrasound waves releases the nucleic acid cargo near tumor cells. Several preclinical studies demonstrated successful microbubble-mediated transfer of nucleic acid to the tumor site. ${ }^{27-29}$ Cellular uptake of nucleic acids is facilitated by lipids in the shell, and by the acoustic frequency and force of cavitation of microbubbles. ${ }^{30}$ In comparison to direct inoculation of tumors with antineoplastic agents or nucleic acids, this technique shows greater delivery efficiency and cellular uptake in in vivo models with HNSCC tumors. ${ }^{31,32}$ However, the use of microbubbles is limited to tumors that can be easily visualized using ultrasound imaging.

Significant advances in molecular engineering of viruses enable highly efficient transfer of transgenes into tumors. Adenoviruses and retroviruses are the two main classes of viral vectors tested in HNSCC. Adenoviruses are DNA viruses that infect both dividing and non-dividing cells. Exogenous DNA remains episomal without integrating into the genome. In contrast, retroviruses primarily infect actively dividing cells and stably integrate transgenes into the host genomic DNA with high efficiency. In addition to high efficiency of gene transfer, cell lysis during viral replication potentiates the therapeutic benefit of viruses. Wild-type adenoviruses have a low transfection efficiency; ${ }^{33}$ however, modifications to the viral genome or surface structure have been employed to increase effectiveness. ${ }^{34}$ In order to increase tumor specificity, oncolytic viruses are biochemically modified to target and replicate only within tumor cells or in cells expressing specific genes. In the following sections, we describe the use of gene delivery vectors in preclinical and clinical studies using nucleic acid-based therapy approaches in HNSCC.

\section{DNA-BASED APPROACHES}

There are over 1000 cancer clinical trials testing gene therapy approaches in various cancers (Figure 2). In the following sections, 


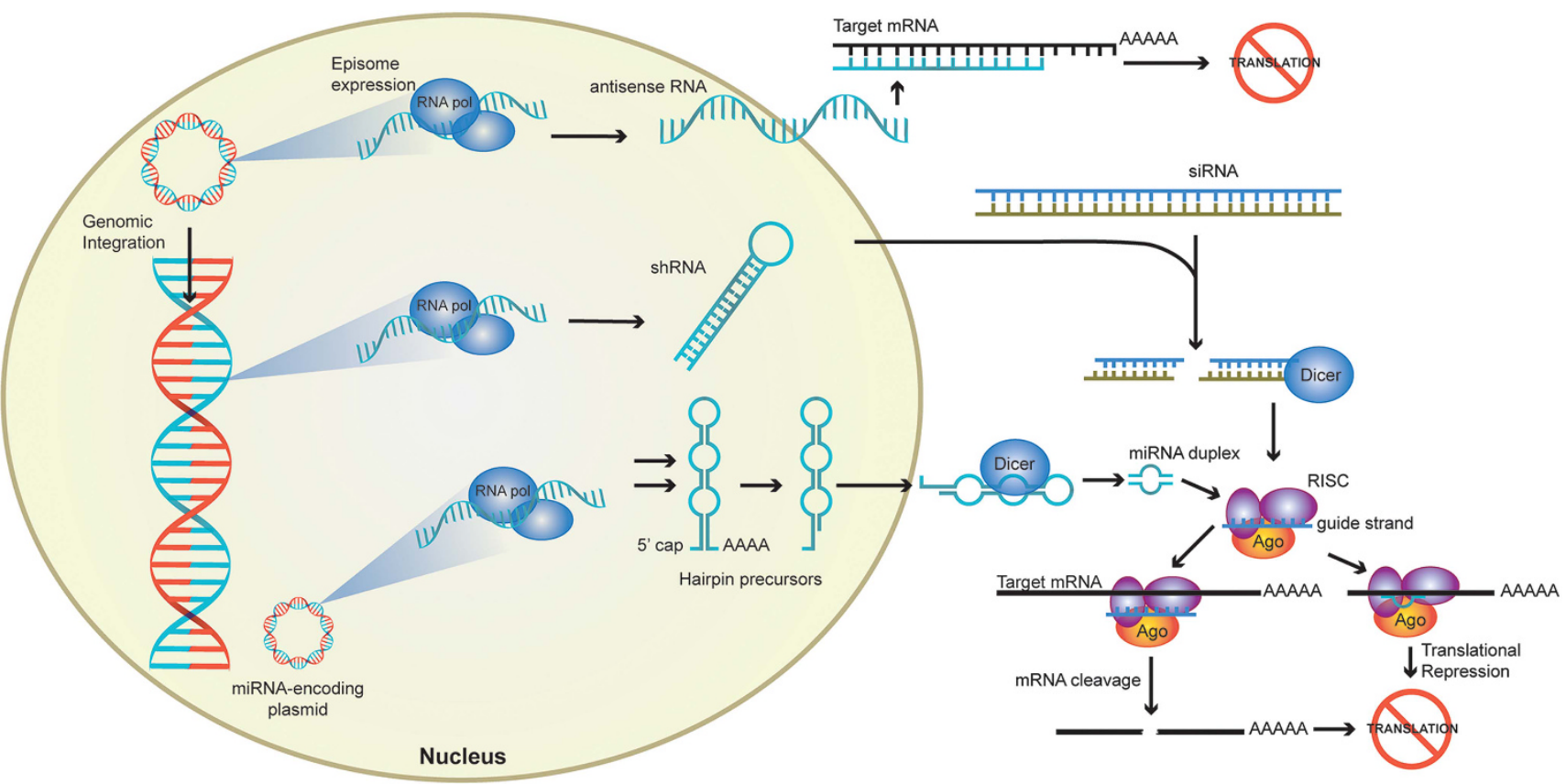

Figure 2. Summary of the methods used for targeting gene expression in the treatment of HNSCC. Exogenous plasmid or viral DNA can stably integrate into the genomic DNA or exist as an episome within the nucleus. RNA polymerases (RNA pol) transcribe the foreign DNA into RNA fragments. Antisense RNA binds to target mRNA in the cytoplasm inhibiting transcription. RNAi-mediated translation inhibition is achieved after processing of double-stranded shRNA, siRNA, or miRNA precursor molecules by molecular machinery. Precursor miRNA are processed in the nucleus and subsequently exported into the cytoplasm. Dicer cleaves shRNA, siRNA, and miRNA precursors into 21-25 base oligomers that are loaded onto the RNA-induced silencing complex loading complex, which consist of Dicer, argonaute (Ago), and a dsRNA-binding protein. The guide strand (blue) binds complementary mRNA while the passenger strand is discarded. Perfect homology with the guide strand triggers target mRNA cleavage. Mismatch in a few bases results in translational repression through inhibition of ribosomal function. Abbreviations: RNAi, RNA interference; miRNA, microRNA.

we describe preclinical and clinical studies utilizing gene therapy for treatment of HNSCC.

\section{Plasmid DNA}

Preclinical studies. Plasmid expression vectors that knockdown oncogenes or restore tumor suppressor genes demonstrate antitumor efficacy in HNSCC preclinical models. Liposomeencapsulated antisense plasmid DNA reduced EGFR mRNA levels and inhibited HNSCC tumor growth ${ }^{35}$ and angiogenesis when used in combination with antiangiogenic agent, endostatin. ${ }^{36}$ The formulation was safe in animal models despite long-term persistence of exogenous plasmid DNA in plasma and organs distant from the injection site. ${ }^{37,38}$ Plasmid expression vectormediated restoration of tumor suppressor p53 levels in HNSCC cell lines activated proapoptotic proteins, promoting tumor death and increased radiosensitivity. ${ }^{20,21}$ Immune-mediated antitumor effects are observed when human interleukin (IL-2)- and IL-27encoding plasmid were transfected into HNSCC tumors. ${ }^{39,40}$ In another approach, toxin-conjugated IL-13 demonstrated specific tumor cell kill in cells transfected with exogenous interleukin-13 receptor a $2 .^{41}$ Although, plasmid expression vectors demonstrate feasibility, systemic delivery continues to be a major challenge in the widespread use of this approach.

Human trials. The majority of HNSCC clinical trials report use of plasmid expression vectors injected intratumorally using cationic liposomes (Table 1). A phase I clinical trial assessing the intratumoral injection of naked plasmid DNA with an antisense sequence targeting EGFR demonstrated a clinical response in $29 \%$ of patients, well above the response rate seen with other EGFRinhibiting agents. ${ }^{42}$ The highest dose administered (1920 $\mu$ g DNA) was well tolerated with no dose-limiting toxicities. Similar efficacy and safety profiles have been demonstrated with intratumoral injection of naked heat-shock protein 65 (Hsp65) DNA. ${ }^{43}$ Hsp65 DNA produced a partial response in 4 of 14 HNSCC patients with minimal adverse effects. Although there is evidence of efficacy in both these clinical trials, tumors inaccessible for direct injection continued to grow. ${ }^{42}$ In order to protect DNA from serum nucleases and improve cellular uptake, several trials have tested cationic liposomes as carriers for gene delivery.

Intratumoral injection of cationic liposomes carrying plasmid DNA encoding $E 1 A$, an adenoviral gene with antineoplastic activity, in HNSCC tumors was well tolerated, demonstrated transgene expression and moderate tumor response with one of 24 patients experiencing complete remission. ${ }^{44}$ Allovectin-7, a DNA-lipid complex containing human leukocyte antigen B7encoding plasmids, has shown modest clinical response and minimal toxicity with intratumoral injection. ${ }^{45,46}$ Human leukocyte antigen B7 is a major histocompatibility complex class I antigen that elicits a broad antitumor immune response. Although results from phase II trials were encouraging, failure to meet key end points in a subsequent trial resulted in the discontinuation of Allovectin-7. Thus, although the proof-of-concept demonstrating antitumor efficacy by plasmid DNA expression vectors is established, the major limitation of susceptibility to serum nucleases remains.

\section{Oligonucleotides}

Oligonucleotides are short, single-stranded, 15-20-base sequences that bind complementary mRNA inhibiting translation primarily through RNase $\mathrm{H}$-mediated degradation. Ideally, the complementary sequence needs to be unique to facilitate specific target 
modulation. Frequently oncogenic mutations differ from wild-type sequences by a few bases. Development of oligonucleotide chemistries such that mismatch of even a single base pair would abrogate binding of antisense oligonucleotide to its target would be ideal for cancer therapeutics and personalized medicine.

Preclinical studies. Antisense DNA oligonucleotides (ASO) targeting EGFR demonstrate antitumor efficacy in HNSCC on intratumoral administration. ${ }^{47}$ Further, the observed effects were sequence specific with lack of antitumor effects in control (sense) oligonucleotide-treated tumors. Substitution of nuclease-resistant phosphorothioate groups to alternate bases on the DNA backbone increases the serum half-life from approximately $5 \mathrm{~min}$ to up to $60 \mathrm{~min}^{48}$ Phosphorothioate-modified EGFR ASO potentiated the effects of docetaxel in HNSCC xenografts on systemic administration. ${ }^{49,50}$ However, the antitumor effects were modest given the relatively short serum half-life.

In order to increase the serum stability of ASOs, peptide nucleic acids (PNAs) were developed. ${ }^{51}$ These are nucleotide analogs containing $\mathrm{N}$-(2-aminoethyl) glycine units in place of the sugar phosphodiester backbone. Despite longer serum half-lives, there is low cellular uptake due to the neutral charge of the backbone. In order to improve intracellular uptake, positively charged guanidinium residues were covalently linked to the peptide nucleic acid backbone (Figure 3). Uptake of guanidinium peptide nucleic acid oligomers was detected in tumors up to $4 \mathrm{~h}$ after systemic administration. ${ }^{49}$ Guanidinium peptide nucleic acid designed to target EGFR has demonstrated sequence-specific target reduction and cytotoxicity in HNSCC cells. Further, the antitumor effects observed are comparable to that of clinically relevant EGFR inhibitors. Changes in the position of the guanidinium group on the peptide nucleic acid backbone facilitated the development of guanidinium peptide nucleic acid that is conformationally preorganized into right-handed helices with higher target binding affinity and sequence specificity than earlier versions. ${ }^{52}$ This increased oligonucleotide serum stability makes systemic delivery of specific nucleic acid sequences for cancer therapy a possibility.

Signal transducer and activator of transcription 3 (STAT3) is a transcription factor that is upregulated in HNSCC and facilitates tumor progression by binding to specific promoter sequences of several tumorigenic genes. Leong and colleagues developed a double-stranded DNA oligonucleotide based on the STAT3-high serum inducible element promoter sequence. ${ }^{53}$ The STAT3 decoy sequestered activated STAT3, preventing binding to the promoter of target genes. ${ }^{53}$ When tested as monotherapy or in combination with erlotinib, STAT3 decoy has antiangiogenic and antitumor effects in xenograft tumors. ${ }^{54,55}$ In another study, guanine-rich oligonucleotides with the high serum inducible element formed G-quartet DNA structures with potent affinity for activated STAT3. ${ }^{56}$ Further, intraperitoneal injections of polyethylenimine copolymers complexed to G-quartet oligomers induced antitumor effects in HNSCC xenografts. More recently, a third-generation ASO targeting Hsp27 was designed using locked nucleic acid technology modified with a ribose oxymethylene bridge to prevent serum degradation. ${ }^{57}$ Intraperitoneal injection of Hsp27 locked nucleic acid led to increased radiosensitivity in HNSCC xenografts through dysregulation of DNA double-stranded break repair mechanisms.

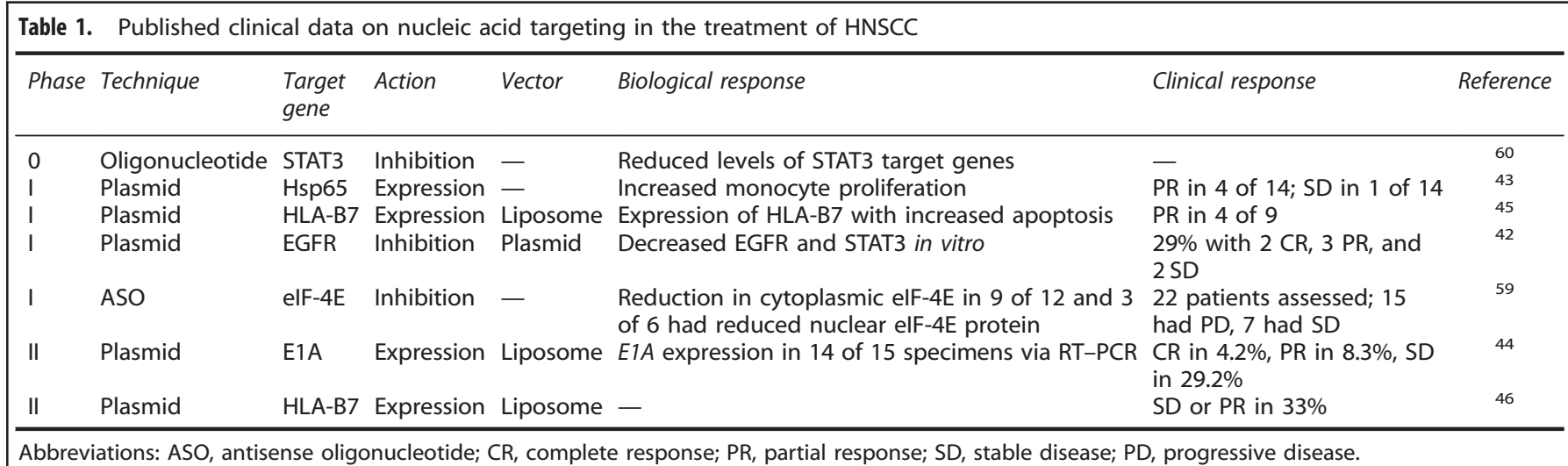

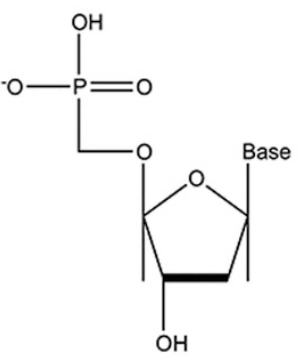

Nucleotide

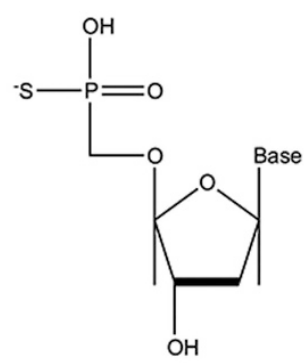

PTO

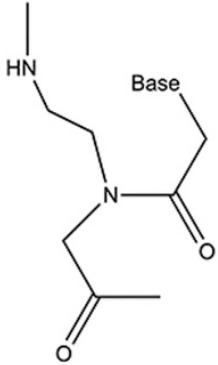

PNA

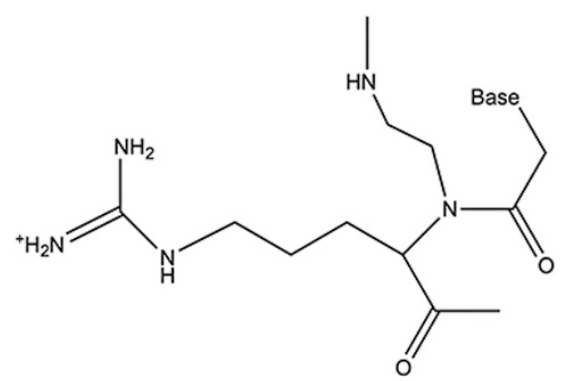

GPNA

Figure 3. Chemical modifications of oligonucleotide backbones. Phosphorothioate-modified oligonucleotides (PTO) are formed by creating phosphorothioate bonds through the substitution of a sulfur atom for a non-bridging oxygen in the phosphate backbone. Peptide nucleic acids (PNAs) are DNA analogs with backbones consisting of $\mathrm{N}$-(2-aminoethyl)-glycine units linked by peptide bonds. The addition of a positively charged guanidinium group to the PNA backbone (GPNA) facilitates oligomer uptake across cell membranes. Abbreviation: GPNA, guanidinium peptide nucleic acid. 
Human trials. Clinical trials testing oligonucleotides in HNSCC treatment are in their infancy. The eukaryotic translation initiation factor $4 \mathrm{e}$ (elF-4E) binds the $5^{\prime}$ cap structure of cellular mRNA and is associated with tumor progression. ${ }^{58}$ Intravenous administration of phosphorothioate ASOs with flanking methoxyethyl groups targeting elF-4E- (LY2275796) was tested for toxicity in a phase I trial for multiple cancers including HNSCC. ${ }^{59}$ One patient experienced grade 2 fatigue at the maximum dose tier of $1200 \mathrm{mg}$. The study defined the maximum tolerated dose as $1000 \mathrm{mg}$ administered intravenously as a loading dose over 3 days followed by a weekly maintenance dose. Although a lower level of elF-4E in the tumor indicated a biological response, there were no clinical responses achieved. Pharmacokinetic evaluation revealed the majority of ASOs distributed in tissues within $24 \mathrm{~h}$ of administration. The modifications to the nucleic acid backbone increased the terminal elimination phase half-life to 15 days (4\% overall plasma exposure). To improve clinical responses, selection of patients with high tumor levels of elF-4E or combined treatment with chemotherapy may be necessary.

The biological response of STAT3 decoy was tested in a phase 0 , intraoperative trial. ${ }^{60}$ Pharmacodynamic studies on intratumoral injection of STAT3 decoy oligomers at three doses revealed modulation of STAT3 target genes within $4 \mathrm{~h}$ of administration. There were no adverse effects reported. Although the results in human studies are limited, these early trials support proofof-concept that oligonucleotides can be safe and are effective in modulating target gene levels in HNSCC.

\section{RNA-BASED APPROACHES}

The regulation of translation by small RNA is an evolutionary conserved process. Molecular machinery process double-stranded non-coding RNA into single-stranded fragments that bind to specific target sequences inhibiting mRNA translation. Initial studies primarily focused on use of RNA interference for knockdown of gene expression in order to determine the role of specific genes or pathways in tumorigenesis. However, the specificity and efficiency of target inhibition has made this an attractive therapeutic modality for cancer.

The most wildly used classes of RNA interference for translational repression of single genes in HNSCC are small interfering RNA (siRNA) and short hairpin RNA (shRNA). The main difference between siRNA and shRNA is that siRNA regulate gene expression transiently (knockdown duration less than 2 weeks) while shRNA vectors are expressed after genomic integration. ${ }^{61}$ Within the cell, molecular machinery process shRNA and siRNA to generate singlestranded RNA fragments that bind complementary sequences on mRNA, leading to their degradation (Figure 2). Multiple cancerassociated genes can be simultaneously downregulated by microRNA. The extent of homology of microRNA to its target dictates the mechanism of translation repression with highly homologous binding triggering target mRNA cleavage. Partial complementarity would inhibit translation of non-target mRNA through several mechanisms including inhibition of translation initiation (interfering with ribosome recruitment) and deacetylation of mRNA. ${ }^{62}$ Similar to microRNA, several reports demonstrate non-specific modulation of cellular mRNA by siRNA with partial sequence homology to the target indicating that siRNA may have off-target effects. ${ }^{63-65}$ Nevertheless, a deeper understanding of the mechanisms of translation inhibition could result in improved specificity of RNA interference approaches. Here we discuss use of these approaches in HNSCC preclinical models.

\section{Small interfering RNA}

Several reports describe siRNA modulation of target genes reduced HNSCC invasion, proliferation, metastatic dissemination, and enhanced response to therapy (Table 2). Invasion and motility of HNSCC cell lines was significantly decreased using protein kinase $C \varepsilon$ siRNA. ${ }^{66}$ Further, the use of hypoxia inducible factor-1a and aurora $A$ kinase siRNA induced apoptosis and reduced cell proliferation. ${ }^{67,68}$ Other factors have also been the target of treatment, notably the nuclear factor-KB family of proteins, which control gene expression in response to several stimuli including cytokines, growth factors, and infection. Nuclear factor-кB is an important target in HNSCC due to its implication in tumor growth and survival. ${ }^{69}$ It is constitutively expressed in HNSCC and contributes to cisplatin resistance by preventing chromatin condensation through histone acetylation. ${ }^{70}$ When used in combination with histone deacetylase inhibitors, systemic administration of siRNA targeting nuclear factor-KB p65 (RelA), increased antitumor efficacy of cisplatin. ${ }^{71}$ Further, in combination with the proteasome inhibitor bortezomib, nuclear factor-KB siRNA reduced tumor growth. ${ }^{72}$

EGFR-targeted siRNA showed a $90 \%$ reduction in EGFR expression in vitro and enhanced sensitivity to cisplatin, 5-fluorouracil, and docetaxel. ${ }^{73}$ To facilitate systemic administration, siRNAs conjugated to nanoparticles were tested in preclinical models of metastatic HNSCC. Ribonucleotide reductase subunit M2 (RRM2)-targeted siRNA conjugated to nanoparticles produced

Table 2. Putative RNAi targets associated with sequence-specific nucleic acid targeting in HNSCC

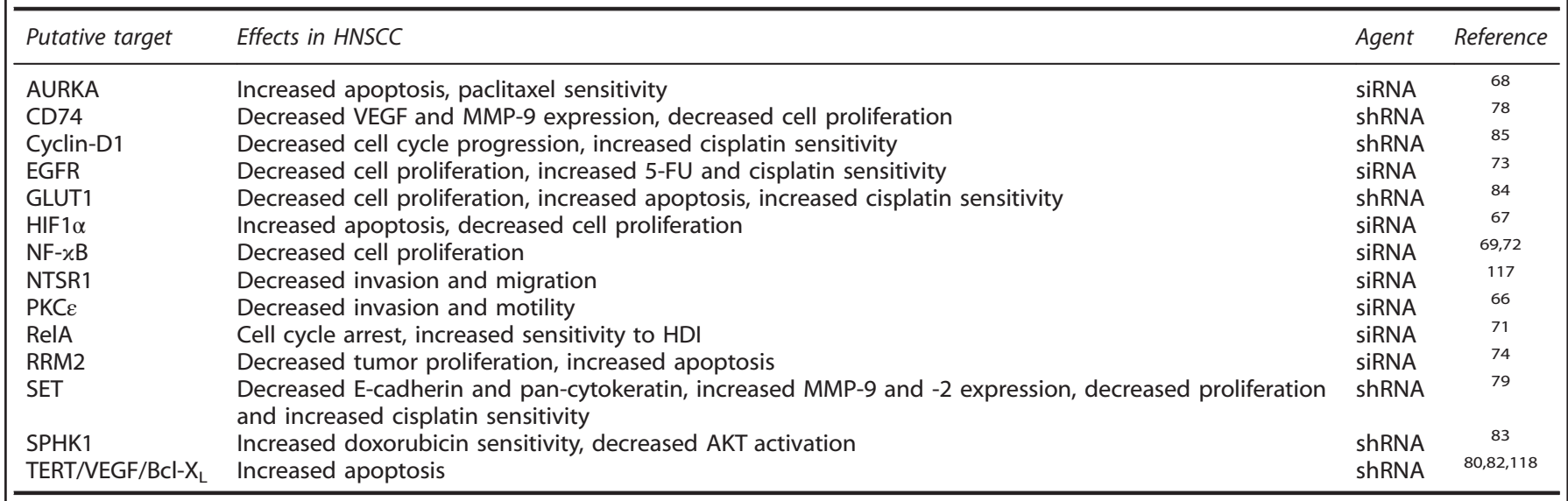

Abbreviations: AURKA, aurora A kinase; HIF1 $\alpha$, hypoxia inducible factor- $1 \alpha$; PKC $\varepsilon$, protein kinase $C \varepsilon$; TERT, telomerase reverse transcriptase; VEGF, vascular endothelial growth factor. 
apoptosis in metastatic models on systemic delivery. ${ }^{74}$ In a recent report, calcium phosphate-based nanoparticles with a hollow lipid-coated core and outer shell conjugated to anisamide ligands successfully delivered hypoxia inducible factor-1 a siRNA to sigma receptor expressing HNSCC cells on intravenous administration. ${ }^{75}$ In combination with a photosensitizer photosan, hypoxia inducible factor-1a siRNA potentiated the effects of photodynamic therapy in xenograft tumors. This study represents a significant advance in siRNA-mediated gene regulation as a therapeutic approach. However, addressing challenges associated with siRNA therapy including off-target effects, inflammation, and nonspecific cytotoxicity would make this approach more feasible for therapeutic use. ${ }^{76}$ While siRNA has not been used in human trials, repression of target protein expression using siRNA has been achieved in vitro, and in vivo studies have demonstrated biologic activity. These results suggest feasibility for their use with reasonable transfection efficiency and significant biological response.

\section{Short hairpin RNA}

Transfection or viral transduction of shRNA expression vectors results in integration into genomic DNA and RNA polymerase IIImediated transcription. ${ }^{77}$ The double-stranded RNA fragments are transcribed in the nucleus with a short hairpin sequence at one end and transported into the cytoplasm where they follow the same molecular processing as siRNA. ${ }^{61}$ Several reports on HNSCC cells expressing target-specific shRNA describe the molecular mechanisms regulating tumor progression and response to therapy.

Reports on shRNA-mediated inhibition of several proteins including CD74 and the SET (suppressor of variegation, enhancer of zeste, and trithorax) oncogene demonstrate antiproliferative effects in HNSCC. ${ }^{78-80}$ Further, local invasion can be controlled by targeting extracellular matrix modulators including metalloproteinase- 9 and $-11 .^{78,81}$ While monotherapy has been efficacious in preclinical models, combination therapy may have synergistic effects. The use of three shRNAs targeting telomerase reverse transcriptase, proangiogenic vascular endothelial growth factor, and antiapoptotic BCl- $\mathrm{X}_{\mathrm{L}}$ genes decreased HNSCC xenograft growth, demonstrating the feasibility of a multitarget-approach. ${ }^{82}$

Several reports demonstrate the role of oncogenes and oncogenic mutations in resistance to therapy. Cisplatin therapy is a vital component of current chemotherapy for HNSCC. However, patients frequently develop resistance to cisplatin. Recent studies have shown that shRNA-mediated downregulation of glucose transporter GLUT1 and cell cycle regulator cyclin-D1 increase sensitivity to cisplatin. ${ }^{83-85}$ Additionally, targeting sphingosine kinase 1 (SPHK1) increased tumor sensitivity to doxorubicin with a significant reduction in SPHK1 expression after transfection. $^{83}$ Similarly, the use of shRNA targeting mutanttumor suppressor $\mathrm{p} 53$ conferred sensitivity to radiation in radioresistant HNSCC. ${ }^{5}$ Although these studies are in preclinical development, developments in vectors including viral vectors would facilitate translation to the clinic. Together these studies provide insight into future applications for therapeutic gene targeting in HNSCC.

\section{VIRAL METHODS}

Viruses are effective transgene delivery agents in treatment of many disease processes ranging from metabolic disturbances to cancer. Of the several classes of viruses used to deliver transgenes, several reports use adenoviruses and herpesviruses in HNSCC preclinical models. While viruses are effective vectors for delivery of genetic material, their lytic life cycles confer the added advantage of tumor cell destruction. In this section, we discuss the use of viruses for gene delivery in HNSCC and advances in oncolytic viruses for targeted destruction of cancer cells.

\section{Viral vectors}

Viruses are frequently used to transduce human cells due to their high efficiency of gene transfer. Depending on the type of virus, the exogenous nucleic acid either integrates into the host genome or remains episomal. Viruses used for gene transfer are generally replication-incompetent though there are exceptions.

Preclinical studies. Adenoviral vectors are the most widely used viral vectors for gene transfer in preclinical studies and clinical trials. Wild-type p53 delivered using recombinant adenoviruses lead to apoptosis in HNSCC tumor cells with up to $60 \%$ response in $48 \mathrm{~h}^{86,87}$ This allows for reestablishment of the $\mathrm{G} 1$ block, increasing sensitivity to radiation and chemotherapy. ${ }^{88-90}$ Further, adenoviruses and adeno-associated viruses were used to deliver herpes thymidine kinase to tumor explants..$^{91-93}$ Treatment with prodrug ganciclovir not only killed the transduced cells but also the adjacent bystander cells. In a recent study, recombinant vaccinia virus encoding the oncogene erbB2 was tested in a vaccination approach in a mouse model of salivary gland carcinoma. ${ }^{94}$ Activation of antibody-dependent cellular cytotoxicity on intratumoral injection of the recombinant virus resulted in antitumor efficacy.

Human trials. Clinical trials have primarily focused on the use of adenoviruses for treatment of HNSCC (Table 3). Gene therapy using adenoviruses encoding wild-type p53 (Ad-p53) was tested in phase I human trials. In patients with incurable recurrent HNSCC, no dose-limiting toxicities or significant adverse events were observed using a single preoperative intratumoral injection of $10^{11}$ plaque-forming units ( $\mathrm{pfu}$ ). Additionally there was a modest response in a number of patients with non-resectable tumors and one patient with resectable cancer showed complete response. Furthermore, there was an increase in survival rate by approximately $60 \%$ of individuals treated with combination Ad-p53 and chemotherapy. ${ }^{90} \mathrm{~A}$ small-scale phase II trial assessing the efficacy of Ad-p53 in patients with resectable cancer demonstrated increased disease-free survival rates 1 year after resection. ${ }^{95}$ The study enrolled 13 patients who received direct injection of $10^{12}$ viral particles (vp) into the surgical margins intraoperatively and postoperatively via catheter instillation. There were minimal adverse events and $92 \%$ of patients were disease free after 1 year. Increased survival and improved response rates were reported in phase III clinical trials as well. The intra-arterial administration of combination Ad-p53 and chemotherapy improved survivability in patients with stage 3 HNSCC. ${ }^{96}$ Response rates significantly increased in comparison to treatment with methotrexate for patients with either wild-type p53 or low-level expression of mutated p53. ${ }^{97}$ Ad-p53 vectors are currently being tested in phase IV clinical trials.

\section{Oncolytic viruses}

Oncolytic viruses preferentially replicate in and lyse tumor cells that express or lack specific targetable genes. In theory, these agents lead to tumor destruction with minimal bystander damage. Newer generation oncolytic viruses carry exogenous genes that elicit antitumor effects or sensitize tumors to therapy.

Preclinical studies. Modified herpes simplex viral (HSV) and adenoviral vectors can carry up to $50 \mathrm{~Kb}$ of DNA transgene, and can preferentially replicate in and lyse tumor cells. Several HSVbased viral vectors were tested in preclinical models of HNSCC. HF10, HSV1716, and G207 vectors shows antitumor efficacy alone or with concomitant cisplatin in HNSCC preclinical models. ${ }^{98-100}$ Both in vitro and in vivo studies showed biologic activity and 
Table 3. Published clinical data on viral vectors in the treatment of HNSCC

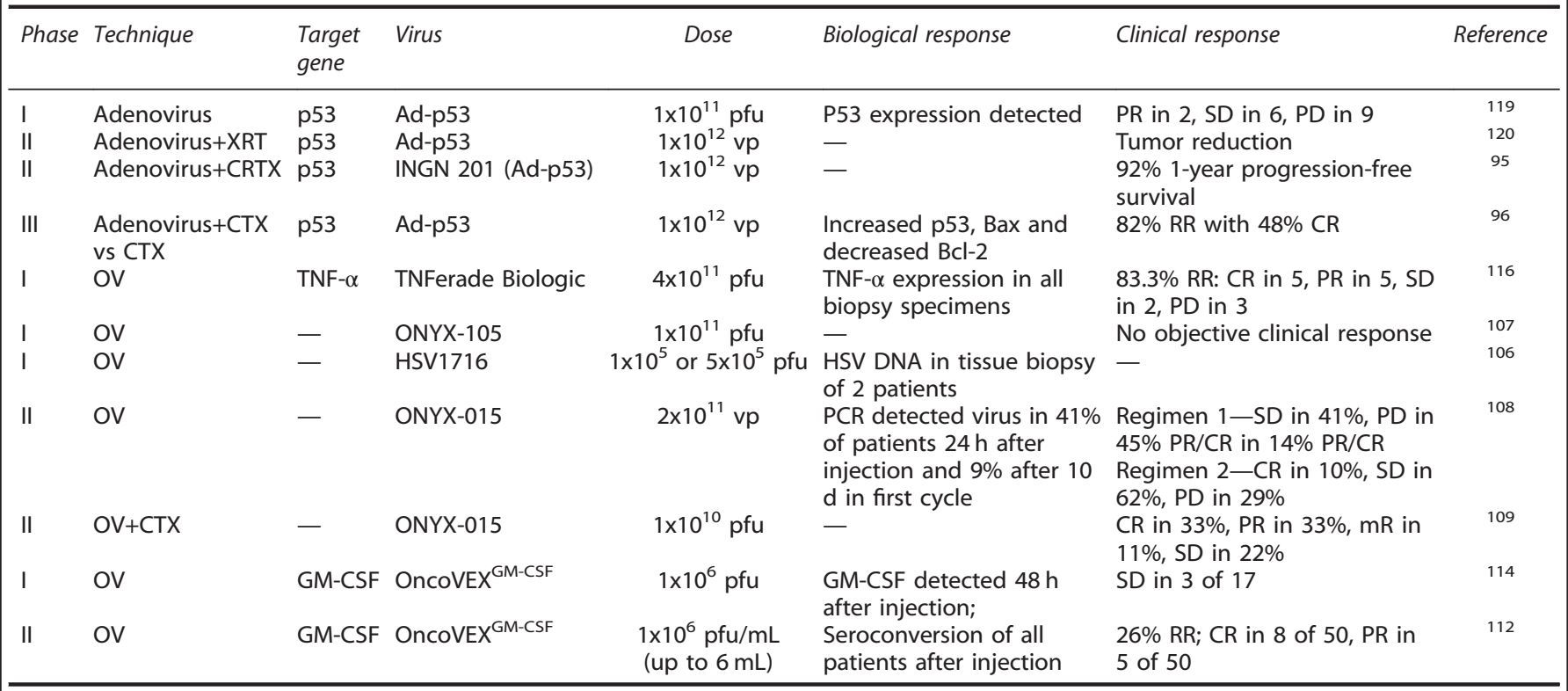

Abbreviations: OV, oncolytic virus; XRT, radiotherapy; CTX, chemotherapy; CRTX, chemoradiotherapy; pfu, plaque-forming units; vp, viral particles; RR, response rate; $C R$, complete response; $P R$, partial response; $m R$, minor response; $S D$, stable disease; $P D$, progressive disease.

destruction of all tumor cell lines. Further, mice with HNSCC xenografts had a statistically significant increase in survivability at 100 days. $^{99}$ The ONYX class of viruses are E1B-gene-deleted adenoviruses that selectively replicate within cells lacking wildtype tumor suppressor p53 and have demonstrated antitumor efficacy in vitro and in vivo. ${ }^{101}$ Intravenous injection of ONYX-015 leads to tumor localization and produces antitumor effects in nude mice bearing xenograft tumors with a viral replication reported in $100 \%$ of tumors. Furthermore, there was a reduction in tumor growth up to $50 \%$ though no appreciable effect on the growth of distant established tumors was observed. ${ }^{102}$ The main obstacle to HSV and adenoviral vectors lie in the endemic nature of the viruses with more than $70 \%$ of the population having a preexisting immune response that specifically inactivates viral particles and cells that express viral proteins. ${ }^{103}$ Preclinical studies with other classes of oncolytic viruses are underway.

In order to facilitate antitumor immune-mediated tumor kill, a fusogenic vesicular stomatitis virus encoding murine IL-12 was developed, which lysed HNSCC more effectively than virus lacking the transgene leading to significantly increased survival of mice. ${ }^{104}$ Another study with measles virus engineered to replace the viral attachment protein with a single-chain antibody targeting EGFR demonstrated increased tumor specificity. ${ }^{105}$ In addition, the virus carried the cytosine deaminase/uracil phosphoribosyltransferase (CD/UPRT) gene. CD/UPRT converts prodrug 5 -fluorocytosine to 5-fluorouracil, which can diffuse from dying cells, significantly increasing antitumor effects in non-infected bystander replicating tumor cells. HNSCC xenograft tumors responded well to intratumoral injections of the recombinant viral particles followed by prodrug treatment. These studies demonstrate efficacy of transgene expression by oncolytic viruses for added therapeutic benefit.

Human trials. Multiple human trials using oncolytic viruses have shown biologic or clinical response (Table 3). Intratumoral injection into subcutaneous nodules of a conditionally replication-competent HSV vector called HF10 in two patients with metastatic HNSCC demonstrated antitumor response with minimal adverse effects. ${ }^{100}$ Although preoperative intratumoral injection of $10^{5}$ pfu of another HSV vector, HSV1761, was well tolerated with no serious adverse effects, there was no biological effect of therapy. ${ }^{106}$ ONYX-015 has demonstrated safety with injection of $10^{11}$ pfu. ${ }^{107}$ Stable disease and modest antitumor activity was achieved with intratumoral administration of ONYX-015. In a small-scale trial of nine patients, $10^{10}$ pfu of ONYX-015 was administered intratumorally with systemic cisplatin and 5-FU leading to complete or partial regression in all subjects. 108 The study was expanded to a larger phase II trial that reported $63 \%$ of individuals with regression. ${ }^{109}$ The commercial version of ONYX-015 (ONYX-H101) has been tested in humans and is approved for human use in China. ${ }^{110}$

Significant advances in the development of oncolytic viruses have enabled the expression of transgenes that trigger antitumor responses in addition to cell lysis. The granulocyte macrophage colony-stimulating factor (GM-CSF) recruits and activates leukocytes including neutrophils and monocytes to elicit potent antitumor effects. GM-CSF was the first cytokine incorporated into an oncolytic virus in order to harness the both immune and virus-mediated tumor cell kill. OncoVEX GM-CSF is a modified HSV-1 encoding GM-CSF tested in several clinical trials. ${ }^{11-113}$ In a phase $\mathrm{I} / \mathrm{II}$ trial, intratumoral injections of OncoVEX $\mathrm{GM}^{\mathrm{CSF}}$ in combination with chemoradiotherapy demonstrated a pathologic complete response rate of $93 \%(n=17)$ in late stage HNSCC. ${ }^{114}$ Pharmacodynamic analyses demonstrated virus replication in injected and uninjected tumors. This study is the first to demonstrate the efficacy of using transgene-expressing oncolytic viruses in combination and standard curative therapy.

In another study, tumor necrosis factor alpha (TNF-a) an immune system stimulator, chemotherapy and radiation sensitizer expressed by an oncolytic virus was tested for antitumor effects in recurrent previously treated HNSCC patients. AdGV.EGR.TNF.11D (TNFerade Biologic) is a replication-deficient adenovirus encoding TNF-a under the control of radiation-inducible Egr-1 promoter. ${ }^{115}$ Dose-limiting toxicity in 3 of 14 patients experiencing thrombotic events on intratumoral injections of TNFerade Biologic at a maximum dose of $4 \times 10^{11}$ pfu combined with chemoradiotherapy 
helped establish the maximum tolerated dose. ${ }^{116}$ Although phase I trials are not designed to assess efficacy, the response rate of $83 \%$, with one patient surviving for 3 years underscores the therapeutic potential of this approach. Further developments facilitating systemic administration and tumor-specific targeting would facilitate the use of oncolytic viruses in the treatment of inaccessible metastatic disease.

\section{CONCLUSIONS}

HNSCC remains a major cause of mortality despite advances in treatment. As more therapeutic targets are identified through cancer genome sequencing studies, nucleic acid targeted therapy has the potential to decrease mortality, increase survival rates, and improve quality of life in patients with HNSCC. The field of nucleic acid targeting is rapidly advancing with new avenues of treatment unfolding. A variety of delivery techniques have been employed for multiple therapy modalities with positive results in both preclinical studies and human trials. Most methods of nucleic acid delivery have been safe in human trials with reduction in target gene expression and evidence of antitumor efficacy.

While there have been clinical trials assessing safety and efficacy of viral vectors, less clinical data are available for the use of antisense oligonucleotides and RNA interference methods. The development of oligonucleotides that target-specific gene mutations within a given tumor could provide a patient-centered approach to therapy. At the very least, nucleic acid targeting has a crucial role in adjunct treatment for HNSCC.

\section{CONFLICT OF INTEREST}

The authors declare no conflict of interest.

\section{ACKNOWLEDGEMENTS}

We thank Dr Hinrich Staecker, Department of Otolaryngology, University of Kansas Medical Center, Kansas City, KS and Dr Stefan Rothenberg, K-State University, Manhattan, KS for critical review of the manuscript. We also thank Mr Phil Shafer for the artwork. We apologize to authors whose work was not cited due to space constraints. Department of Otolaryngology, University of Kansas Medical Center and University of Kansas Cancer Center's CCSG (1-P30-CA168524-02), and the Kansas Intellectual and Developmental Disabilities Center (NICHD HD00258) were the funding sources.

\section{REFERENCES}

1 Döbróssy L. Epidemiology of head and neck cancer: magnitude of the problem. Cancer Metastasis Rev 2005; 24: 9-17.

2 Accardi R, Adebamowo C, Anderson B, Autier P, Baan R, Barbacid M et al. Head and neck cancers. In: Boyle P, Levin B (eds). World Cancer Report 2008. International Agency for Research on Cancer: Lyon, 2008, pp 30-337.

3 Cohen EEW, Lingen MW, Vokes EE. The expanding role of systemic therapy in head and neck cancer. J Clin Oncol 2004; 22: 1743-1752.

4 The Cancer Genome Atlas Network. Comprehensive genomic characterization of head and neck squamous cell carcinomas. Nature 2015; 517: 576-582.

5 Skinner HD, Sandulache VC, Ow TJ, Meyn RE, Yordy JS, Beadle BM et al. TP53 disruptive mutations lead to head and neck cancer treatment failure through inhibition of radiation-induced senescence. Clin Cancer Res 2012; 18: 290-300.

6 van den Broek GB, Wreesmann VB, van den Brekel MWM, Rasch CRN, Balm AJM, Rao PH. Genetic abnormalities associated with chemoradiation resistance of head and neck squamous cell carcinoma. Clin Cancer Res 2007; 13: 4386-4391.

7 Lui VW, Hedberg ML, Li H, Vangara BS, Pendleton K, Zeng $\mathrm{Y}$ et al. Frequent mutation of the PI3K pathway in head and neck cancer defines predictive biomarkers. Cancer Discov 2013; 3: 761-769.

8 Vermorken JB, Trigo J, Hitt R, Koralewski P, Diaz-Rubio E, Rolland F et al. Open-label, uncontrolled, multicenter phase II study to evaluate the efficacy and toxicity of cetuximab as a single agent in patients with recurrent and/or metastatic squamous cell carcinoma of the head and neck who failed to respond to platinum-based therapy. J Clin Oncol 2007; 25: 2171-2177.

9 Saba NF, Haigentz M Jr, Vermorken JB, Strojan P, Bossi P, Rinaldo A et al. Prevention of head and neck squamous cell carcinoma: removing the "chemo" from "chemoprevention". Oral Oncol 2015; 51: 112-118.

10 Sok JC, Coppelli FM, Thomas SM, Lango MN, Xi S, Hunt JL et al. Mutant epidermal growth factor receptor (EGFRvIII) contributes to head and neck cancer growth and resistance to EGFR targeting. Clin Cancer Res 2006; 12: 5064-5073.

11 Cancer Genome Atlas N, Comprehensive genomic characterization of head and neck squamous cell carcinomas. Nature 2015; 517: 576-582.

12 Lui VWY, Hedberg ML, Li H, Vangara BS, Pendleton K, Zeng $Y$ et al. Frequent mutation of the $\mathrm{PI} 3 \mathrm{~K}$ pathway in head and neck cancer defines predictive biomarkers. Cancer Discov 2013; 3: 761-769.

13 Stransky N, Egloff AM, Tward AD, Kostic AD, Cibulskis K, Sivachenko A et al. The mutational landscape of head and neck squamous cell carcinoma. Science 2011; 333: 1157-1160.

14 Agrawal N, Frederick MJ, Pickering CR, Bettegowda C, Chang K, Li RJ et al. Exome sequencing of head and neck squamous cell carcinoma reveals inactivating mutations in NOTCH1. Science 2011; 333: 1154-1157.

15 Lechardeur D, Sohn KJ, Haardt M, Joshi PB, Monck M, Graham RW et al. Metabolic instability of plasmid DNA in the cytosol: a potential barrier to gene transfer. Gene Ther 1999; 6: 482-497.

16 Konopka K, Overlid N, Nagaraj A, Düzgüneş N. Serum decreases the size of Metafectene-and Genejammer-DNA complexes but does not affect significantly their transfection activity in SCCVII murine squamous cell carcinoma cells. Cell Mol Biol Lett 2006; 11: 171-190.

17 Grandis JR, Drenning SD, Zeng Q, Watkins SC, Melhem MF, Endo S et al. Constitutive activation of Stat3 signaling abrogates apoptosis in squamous cell carcinogenesis in vivo. Proc Natl Acad Sci USA 2000; 97: 4227-4232.

18 Kedmi R, Ben-Arie N, Peer D. The systemic toxicity of positively charged lipid nanoparticles and the role of Toll-like receptor 4 in immune activation. Biomaterials 2010; 31: 6867-6875.

19 Tousignant JD, Gates AL, Ingram LA, Johnson CL, Nietupski JB, Cheng SH et al. Comprehensive analysis of the acute toxicities induced by systemic administration of cationic lipid: plasmid DNA complexes in mice. Hum Gene Ther 2000; 11: 2493-2513.

20 Xu L, Pirollo KF, Tang W-H, Rait A, Chang EH. Transferrin-liposome-mediated systemic p53 gene therapy in combination with radiation results in regression of human head and neck cancer xenografts. Hum Gene Ther 1999; 10: 2941-2952.

21 Xu L, Huang C-C, Huang W, Tang W-H, Rait A, Yin YZ et al. Systemic tumortargeted gene delivery by anti-transferrin Rrceptor scFv-immunoliposomes. Mol Cancer Ther 2002; 1: 337-346.

22 Boussif O, Lezoualc'h F, Zanta MA, Mergny MD, Scherman D, Demeneix B et al. A versatile vector for gene and oligonucleotide transfer into cells in culture and in vivo: polyethylenimine. Proc Natl Acad Sci USA 1995; 92: 7297-7301.

23 Dolivet G, Merlin J-L, Barberi-Heyob M, Ramacci C, Erbacher P, Parache RM et al. In vivo growth inhibitory effect of iterative wild-type p53 gene transfer in human head and neck carcinoma xenografts using glucosylated polyethylenimine nonviral vector. Cancer Gene Ther 2002; 9: 708-714.

24 Ndoye A. Sustained gene transfer and enhanced cell death following glucosylated-PEl-mediated p53 gene transfer with photochemical internalisation in p53-mutated head and neck carcinoma cells. Int J Oncol 2004; 25: 1575-1581.

25 Park I-K, Cook S-E, Kim Y-K, Kim H-W, Cho M-H, Jeong H-J et al. Glucosylated polyethylenimine as a tumor-targeting gene carrier. Arch Pharm Res 2005; 28: 1302-1310.

26 Ren H, Zhou L, Liu M, Lu W, Gao C. Peptide GE11-polyethylene glycol-polyethylenimine for targeted gene delivery in laryngeal cancer. Med Oncol 2015; 32: $1-8$.

27 Sugano M, Negishi Y, Endo-Takahashi Y, Suzuki R, Maruyama K, Yamamoto M et al. Gene delivery system involving Bubble liposomes and ultrasound for the efficient in vivo delivery of genes into mouse tongue tissue. Int J Pharm 2012; 422: 332-337.

28 Carson AR, McTiernan CF, Lavery L, Grata M, Leng X, Wang J et al. Ultrasoundtargeted microbubble destruction to deliver siRNA cancer therapy. Cancer Res 2012; 72: 6191-6199.

29 Suzuki R, Takizawa T, Negishi Y, Hagisawa K, Tanaka K, Sawamura K et al. Gene delivery by combination of novel liposomal bubbles with perfluoropropane and ultrasound. J Control Release 2007; 117: 130-136.

30 Smith NB, Lee S, Maione E, Roy RB, McElligott S, Shung KK. Ultrasound-mediated transdermal transport of insulin in vitro through human skin using novel transducer designs. Ultrasound Med Biol 2003; 29: 311-317.

31 Sorace AG, Korb M, Warram JM, Umphrey H, Zinn KR, Rosenthal E et al. Ultrasound-stimulated drug delivery for treatment of residual disease following 
incomplete resection of head and neck cancer. Ultrasound Med Biol 2014; 40 : 755-764

32 Okunaga S, Takasu A, Meshii N, Imai T, Hamada M, Iwai S et al. Ultrasound as a method to enhance antitumor ability of oncolytic herpes simplex virus for head and neck cancer. Cancer Gene Ther 2015; 22: 163-168.

33 Blackwell JL, Miller C, Douglas JT, Li H, Reynolds PN, Carroll WR et al. Retargeting to EGFR enhances adenovirus infection efficiency of squamous cell carcinoma. Arch Otolaryngol Head Neck Surg 1999; 125: 856-863.

34 Lalonde ES, Beyer G, Friedlander PL, Kolls JK. Efficacy of transfection rates on head and neck squamous cell cancer by a novel adenovirus: an in vivo and in vitro study. Head Neck 2002; 24: 1038-1046.

35 He Y, Zeng Q, Drenning SD, Melhem MF, Tweardy DJ, Huang L et al. EGFR antisense RNA transcribed from the U6 promotor inhibits human squamous cell carcinoma growth in vivo. National Cancer Institute 1998; 90: 1080-1087.

36 Li M, Ye C, Feng C, Riedel F, Liu X, Zeng Q et al. Enhanced antiangiogenic therapy of squamous cell carcinoma by combined endostatin and epidermal growth factor receptor-antisense therapy. Clin Cancer Res 2002; 8: 3570-3578.

37 Zeng Q, Kanter PM, Dhir R, Gooding WE, Huang L, Grandis JR. Lack of toxicity of EGFR antisense gene therapy. J Exp Ther Oncol 2002; 2: 174-186.

38 Thomas SM, Zeng Q, Dyer KF, Suscovich TJ, Kanter PM, Whalen JD et al. Tissue distribution of liposome-mediated epidermal growth factor receptor antisense gene therapy. Cancer Gene Ther 2003; 10: 518-528.

39 Li D, Jiang W, Bishop JS, Ralston R, O'Malley BW. Combination surgery and nonviral interleukin 2 gene therapy for head and neck cancer. Clin Cancer Res 1999; 5: 1551-1556.

40 Matsui M, Kishida T, Nakano H, Yoshimoto K, Shin-Ya M, Shimada T et al. Interleukin-27 activates natural killer cells and suppresses NK-resistant head and neck squamous cell carcinoma through inducing antibody-dependent cellular cytotoxicity. Cancer Res 2009; 69: 2523-2530.

41 Kawakami K, Kawakami M, Joshi BH, Puri RK. Interleukin-13 receptor-targeted cancer therapy in an immunodeficient animal model of human head and neck cancer. Cancer Res 2001; 61: 6194-6200.

42 Lai SY, Koppikar P, Thomas SM, Childs EE, Egloff AM, Seethala RR et al. Intratumoral epidermal growth factor receptor antisense DNA therapy in head and neck cancer: first human application and potential antitumor mechanisms. J Clin Oncol 2009; 27: 1235-1242.

43 Michaluart P, Abdallah KA, Lima FD, Smith R, Moyses RA, Coelho V et al. Phase I trial of DNA-hsp65 immunotherapy for advanced squamous cell carcinoma of the head and neck. Cancer Gene Ther 2008; 15: 676-684.

44 Villaret D, Glisson B, Kenady D, Hanna E, Carey M, Gleich L et al. A multicenter phase II study of $\operatorname{tgDCC}-\mathrm{E} 1 \mathrm{~A}$ for the intratumoral treatment of patients with recurrent head and neck squamous cell carcinoma. Head Neck 2002; 24: 661-669.

45 Gleich LL, Gluckman JL, Armstrong S, Biddinger PW, Miller MA, Balakrishnan K et al. Alloantigen gene therapy for squamous cell carcinoma of the head and neck: results of a phase 1 trial. Arch Otolaryngol Head Neck Surg 1998; 124: 1097-1104.

46 Gleich LL, Gluckman JL, Nemunaitis J, Suen JY, Hanna E, Wolf GT et al. Clinical experience with HLA-B7 plasmid DNA/lipid complex in advanced squamous cell carcinoma of the head and neck. Arch Otolaryngol Head Neck Surg 2001; 127: 775-779.

47 Grandis JR, Chakraborty A, Melhem MF, Zeng Q, Tweardy DJ. Inhibition of epidermal growth factor receptor gene expression and function decreases proliferation of head and neck squamous carcinoma but not normal mucosal epithelial cells. Oncogene 1997; 15: 409-416.

48 Yuen AR, Halsey J, Fisher GA, Holmlund JT, Geary RS, Kwoh TJ et al. Phase I study of an antisense oligonucleotide to protein kinase C-a (ISIS 3521/CGP 64128A) in patients with cancer. Clin Cancer Res 1999; 5: 3357-3363.

49 Thomas SM, Sahu B, Rapireddy S, Bahal R, Wheeler SE, Procopio EM et al. Antitumor effects of EGFR antisense guanidine-based peptide nucleic acids in cancer models. ACS Chem Biol 2012; 8: 345-352.

50 Thomas SM, Ogagan MJ, Freilino ML, Strychor S, Walsh DR, Gooding WE et al. Antitumor mechanisms of systemically administered epidermal growth factor receptor antisense oligonucleotides in combination with docetaxel in squamous cell carcinoma of the head and neck. Mol Pharmacol 2008; 73: 627-638.

51 Demidov VV, Potaman VN, Frank-Kamenetskil MD, Egholm M, Buchard O, Sönnichsen SH et al. Stability of peptide nucleic acids in human serum and cellular extracts. Biochem Pharmacol 1994; 48: 1310-1313.

52 Sahu B, Chenna V, Lathrop KL, Thomas SM, Zon G, Livak KJ et al. Synthesis of conformationally preorganized and cell-permeable guanidinebased gamma-peptide nucleic acids (gammaGPNAs). J Org Chem 2009; 74: 1509-1516.
53 Leong PL, Andrews GA, Johnson DE, Dyer KF, Xi S, Mai JC et al. Targeted inhibition of Stat3 with a decoy oligonucleotide abrogates head and neck cancer cell growth. Proc Natl Acad Sci USA 2003; 100: 4138-4143.

54 Boehm AL, Sen M, Seethala R, Gooding WE, Freilino M, Wong SMY et al. Combined targeting of epidermal growth factor receptor, signal transducer and activator of transcription-3, and $\mathrm{BCl}-\mathrm{XL}$ enhances antitumor effects in squamous cell carcinoma of the head and neck. Mol Pharmacol 2008; 73: 1632-1642.

55 Klein JD, Sano D, Sen M, Myers JN, Grandis JR, Kim S. STAT3 oligonucleotide inhibits tumor angiogenesis in preclinical models of squamous cell carcinoma. PloS one 2014; 9: e81819.

56 Jing N, Zhu Q, Yuan P, Li Y, Mao L, Tweardy DJ. Targeting signal transducer and activator of transcription 3 with G-quartet oligonucleotides: a potential novel therapy for head and neck cancer. Mol Cancer Ther 2006; 5: 279-286.

57 Guttmann DM, Hart L, Du K, Seletsky A, Koumenis C. Inhibition of Hsp27 radiosensitizes head-and-neck cancer by modulating deoxyribonucleic acid repair. Int J Radiat Oncol Biol Phys 2013; 87: 168-175.

58 Graff JR, Konicek BW, Vincent TM, Lynch RL, Monteith D, Weir SN et al. Therapeutic suppression of translation initiation factor elF4E expression reduces tumor growth without toxicity. J Clin Invest 2007; 117: 2638-2648.

59 Hong DS, Kurzrock R, Oh Y, Wheler J, Naing A, Brail L et al. A phase 1 dose escalation, pharmacokinetic, and pharmacodynamic evaluation of elF-4E antisense oligonucleotide LY2275796 in patients with advanced cancer. Clin Cancer Res 2011; 17: 6582-6591.

60 Sen M, Thomas SM, Kim S, Yeh JI, Ferris RL, Johnson JT et al. First-in-human trial of a STAT3 decoy oligonucleotide in head and neck tumors: implications for cancer therapy. Cancer Discov 2012; 2: 694-705.

61 Mansoori B, Shotorbani SS, Baradaran B. RNA interference and its role in cance therapy. Adv Pharm Bull 2014; 4: 313-321.

62 Fabian MR, Sonenberg N. The mechanics of miRNA-mediated gene silencing: a look under the hood of miRISC. Nat Struct Mol Biol 2012; 19: 586-593.

63 Jackson AL, Burchard J, Schelter J, Chau BN, Cleary M, Lim L et al. Widespread siRNA "off-target" transcript silencing mediated by seed region sequence complementarity. RNA 2006; 12: 1179-1187.

64 Persengiev SP, Zhu X, Green MR. Nonspecific, concentration-dependent stimulation and repression of mammalian gene expression by small interfering RNAs (siRNAs). RNA 2004; 10: 12-18.

65 Doench JG, Petersen CP, Sharp PA. siRNAs can function as miRNAs. Genes Dev 2003; 17: 438-442.

66 Pan Q, Bao LW, Teknos TN, Merajver SD. Targeted disruption of protein kinase $\mathrm{C} \varepsilon$ reduces cell invasion and motility through inactivation of RhoA and RhoC GTPases in head and neck squamous cell carcinoma. Cancer Res 2006; 66 9379-9384.

67 Zhang Q, Zhang ZF, Rao JY, Sato JD, Brown J, Messadi DV et al. Treatment with siRNA and antisense oligonucleotides targeted to HIF-1a induced apoptosis in human tongue squamous cell carcinomas. Int J Cancer 2004; 111: 849-857.

68 Mazumdar A, Henderson YC, El-Naggar AK, Sen S, Clayman GL. Aurora kinase A inhibition and paclitaxel as targeted combination therapy for head and neck squamous cell carcinoma. Head Neck 2009; 31: 625-634.

69 Ferris RL, Grandis JR. NF-KB gene signatures and p53 mutations in head and neck squamous cell carcinoma. Clin Cancer Res 2007; 13: 5663-5664.

70 Loercher A, Lee TL, Ricker JL, Howard A, Geoghegen J, Chen Z et al. Nuclear factor-кB is an important modulator of the altered gene expression profile and malignant phenotype in squamous cell carcinoma. Cancer Res 2004; 64: 6511-6523.

71 Duan J, Friedman J, Nottingham L, Chen Z, Ara G, Van Waes C. Nuclear factor-kB p65 small interfering RNA or proteasome inhibitor bortezomib sensitizes head and neck squamous cell carcinomas to classic histone deacetylase inhibitors and novel histone deacetylase inhibitor PXD101. Mol Cancer Ther 2007; 6: 37-50.

72 Lun M, Zhang PL, Pellitteri PK, Law A, Kennedy TL, Brown RE. Nuclear factor-KB pathway as a therapeutic target in head and neck squamous cell carcinoma: pharmaceutical and molecular validation in human cell lines using Velcade and siRNA/NF-kB. Ann Clin Lab Sci 2005; 35: 251-258.

73 Nozawa H, Tadakuma T, Ono T, Sato M, Hiroi S, Masumoto $\mathrm{K}$ et al. Small interfering RNA targeting epidermal growth factor receptor enhances chemosensitivity to cisplatin, 5-fluorouracil and docetaxel in head and neck squamous cell carcinoma. Cancer Sci 2006; 97: 1115-1124.

74 Rahman MA, Amin ARM, Wang X, Zuckerman JE, Choi CHJ, Zhou B et al. Systemic delivery of siRNA nanoparticles targeting RRM2 suppresses head and neck tumor growth. J Control Release 2012; 159: 384-392.

75 Chen WH, Lecaros RL, Tseng YC, Huang L, Hsu YC. Nanoparticle delivery of HIF1alpha siRNA combined with photodynamic therapy as a potential treatment strategy for head-and-neck cancer. Cancer Lett 2015; 359: 65-74.

76 Rao DD, Vorhies JS, Senzer N, Nemunaitis J. siRNA vs. shRNA: similarities and differences. Adv Drug Deliv Rev 2009; 61: 746-759. 
77 Deng Y, Wang CC, Choy KW, Du Q, Chen J, Wang Q et al. Therapeutic potentials of gene silencing by RNA interference: Principles, challenges, and new strategies. Gene 2014; 538: 217-227.

78 Kindt N, Lechien J, Nonclercq D, Laurent G, Saussez S. Involvement of CD74 in head and neck squamous cell carcinomas. J Cancer Res Clin Oncol 2014; 140: 937-947.

79 Sobral LM, Sousa LO, Coletta RD, Cabral H, Greene LJ, Tajara EH et al. Stable SET knockdown in head and neck squamous cell carcinoma promotes cell invasion and the mesenchymal-like phenotype in vitro, as well as necrosis, cisplatin sensitivity and lymph node metastasis in xenograft tumor models. Mol Cancer 2014; 13: 32-32.

80 Liu D, Tao Z-Z, Xiao B-K, Chen S, Chi H. Inhibitory effect of silencing hTERT gene by short hairpin RNA on growth of human laryngeal squamous cell carcinoma xenograft in nude mice. Ai Zheng 2006; 25: 11-16.

$81 \mathrm{H} \sin \mathrm{C}-\mathrm{H}$, Chen M-K, Tang C-H, Lin H-P, Chou M-Y, Lin C-W et al. High level of plasma matrix metalloproteinase-11 is associated with clinicopathological characteristics in patients with oral squamous cell carcinoma. PLoS One 2014; 9: e113129.

82 Chen S-M, Wang Y, Xiao B-K, Tao Z-Z. Effect of blocking VEGF, hTERT and Bcl-xl by multiple shRNA expression vectors on the human laryngeal squamous carcinoma xenograft in nude mice. Cancer Biol Ther 2008; 7: 734-739.

83 Hazar-Rethinam M, Merida de Long L, Gannon O, Topkas E, Boros S, Vargas AC et al. A novel E2F/Sphingosine kinase 1 axis regulates anthracycline response in squamous cell carcinoma. Clin Cancer Res 2014; 21: 417-427.

84 Wang Y-D, Li S-J, Liao J-X. Inhibition of glucose transporter 1 (GLUT1) chemosensitized head and neck cancer cells to cisplatin. Technol Cancer Res Treat 2013; 12: $525-535$.

85 Kothari V, Mulherkar R. Inhibition of cyclin D1 by shRNA is associated with enhanced sensitivity to conventional therapies for head and neck squamous cell carcinoma. Anticancer Res 2012; 32: 121-128.

86 Tassone P, Old M, Teknos TN, Pan Q. p53-based therapeutics for head and neck squamous cell carcinoma. Oral Oncol 2013; 49: 733-737.

87 Liu T-J, El-Naggar AK, McDonnell TJ, Steck KD, Wang M, Taylor DL et al. Apoptosis induction mediated by wild-type p53 adenoviral gene transfer in squamous cell carcinoma of the head and neck. Cancer Res 1995; 55: 3117-3122.

88 Xu L, Tang W-H, Huang C-C, Alexander W, Xiang L-M, Pirollo KF et al. Systemic p53 gene therapy of cancer with immunolipoplexes targeted by anti-transferrin receptor scFv. Mol Med 2001; 7: 723.

89 Chang EH, Jang Y-J, Hao Z, Murphy G, Rait A, Fee WE Jr et al. Restoration of the G1 checkpoint and the apoptotic pathway mediated by wild-type $\mathrm{p} 53$ sensitizes squamous cell carcinoma of the head and neck to radiotherapy. Arch Otolaryngol Head Neck Surg 1997; 123: 507.

90 Clayman GL, Frank DK, Bruso PA, Goepfert H. Adenovirus-mediated wild-type p53 gene transfer as a surgical adjuvant in advanced head and neck cancers. Clin Cancer Res 1999; 5: 1715-1722.

91 O'Malley BW, Chen S-H, Schwartz MR, Woo SLC. Adenovirus-mediated gene therapy for human head and neck squamous cell cancer in a nude mouse model. Cancer Res 1995; 55: 1080-1085.

92 Morris JC, Wildner O. Therapy of head and neck squamous cell carcinoma with an oncolytic adenovirus expressing HSV-tk. Mol Ther 2000; 1: 56-62.

93 Kanazawa T, Mizukami H, Okada T, Hanazono Y, Kume A, Nishino H et al. Suicide gene therapy using AAV-HSVtk/ganciclovir in combination with irradiation results in regression of human head and neck cancer xenografts in nude mice. Gene Ther 2003; 10: 51-58.

94 Masuelli L, Fantini M, Benvenuto M, Sacchetti P, Giganti MG, Tresoldi I et al. Intratumoral delivery of recombinant vaccinia virus encoding for ErbB2/Neu inhibits the growth of salivary gland carcinoma cells. J Transl Med 2014; 12: 122.

95 Yoo GH, Moon J, LeBlanc M, Lonardo F, Urba S, Kim H et al. A phase 2 trial of surgery with perioperative INGN 201 (Ad5CMV-p53) gene therapy followed by chemoradiotherapy for advanced, resectable squamous cell carcinoma of the oral cavity, oropharynx, hypopharynx, and larynx: report of the Southwest Oncology Group. Arch Otolaryngol Head Neck Surg 2009; 135: 869-874.

96 Li Y, Li L-J, Wang L-J, Zhang Z, Gao N, Liang C-Y et al. Selective intra-arterial infusion of rAd-p53 with chemotherapy for advanced oral cancer: a randomized clinical trial. BMC Med 2014; 12: 16-16.

97 Nemunaitis J, Clayman G, Agarwala SS, Hrushesky W, Wells JR, Moore C et al. Biomarkers predict p53 gene therapy efficacy in recurrent squamous cell carcinoma of the head and neck. Clin Cancer Res 2009; 15: 7719-7725.

98 Mace ATM, Harrow SJ, Ganly I, Brown SM. Cytotoxic effects of the oncolytic herpes simplex virus HSV1716 alone and in combination with cisplatin in head and neck squamous cell carcinoma. Acta Otolaryngol (Stockh) 2007; 127: 880-887.

99 Chahlavi A, Todo T, Martuza RL, Rabkin SD. Replication-competent herpes simplex virus vector $\mathrm{G} 207$ and cisplatin combination therapy for head and neck squamous cell carcinoma. Neoplasia 1999; 1: 162-169.
100 Fujimoto Y, Mizuno T, Sugiura S, Goshima F, Kohno S-I, Nakashima T et al. Intratumoral injection of herpes simplex virus HF10 in recurrent head and neck squamous cell carcinoma. Acta Otolaryngol (Stockh) 2006; 126: 1115-1117.

101 Bischoff JR, Kirn DH, Williams A, Heise C, Horn S, Muna M et al. An adenovirus mutant that replicates selectively in p53-deficient human tumor cells. Science 1996; 274: 373-376.

102 Heise CC, Williams AM, Xue S, Propst M, Kirn DH. Intravenous administration of ONYX-015, a selectively replicating adenovirus, induces antitumoral efficacy. Cancer Res 1999; 59: 2623-2628.

103 Vannucci L, Lai M, Chiuppesi F, Ceccherini-Nelli L, Pistello M. Viral vectors: a look back and ahead on gene transfer technology. New Microbiol 2013; 36: $1-22$.

104 Shin EJ, Wanna GB, Choi B, Aguila D, Ebert O, Genden EM et al. Interleukin-12 expression enhances vesicular stomatitis virus oncolytic therapy in murine squamous cell carcinoma. Laryngoscope 2007; 117: 210-214.

105 Zaoui K, Bossow S, Grossardt C, Leber MF, Springfeld C, Plinkert PK et al. Chemovirotherapy for head and neck squamous cell carcinoma with EGFRtargeted and CD/UPRT-armed oncolytic measles virus. Cancer Gene Ther 2011; 19: 181-191.

106 Mace A, Ganly I, Soutar DS, Brown SM. Potential for efficacy of the oncolytic Herpes simplex virus 1716 in patients with oral squamous cell carcinoma. Head Neck 2008; 30: 1045-1051.

107 Ganly I, Kirn D, Eckhardt SG, Rodriguez GI, Soutar DS, Otto R et al. A phase I study of Onyx-015, an E1B attenuated adenovirus, administered intratumorally to patients with recurrent head and neck cancer. Clin Cancer Res 2000; 6: 798-806.

108 Nemunaitis J, Khuri F, Ganly I, Arseneau J, Posner M, Vokes E et al. Phase II trial of intratumoral administration of ONYX-015, a replication-selective adenovirus, in patients with refractory head and neck cancer. J Clin Oncol 2001; 19: 289-298.

109 Lamont JP, Nemunaitis J, Kuhn JA, Landers SA, McCarty TM. A prospective phase II trial of ONYX-015 adenovirus and chemotherapy in recurrent squamous cell carcinoma of the head and neck (the Baylor experience). Ann Surg Oncol 2000; 7: 588-592.

110 Garber K. China approves world's first oncolytic virus therapy for cancer treatment. J Natl Cancer Inst 2006; 98: 298-300.

111 Hu JC, Coffin RS, Davis CJ, Graham NJ, Groves N, Guest PJ et al. A phase I study of OncoVEXGM-CSF, a second-generation oncolytic herpes simplex virus expressing granulocyte macrophage colony-stimulating factor. Clin Cancer Res 2006; 12: 6737-6747.

112 Senzer NN, Kaufman HL, Amatruda T, Nemunaitis M, Reid T, Daniels G et al. Phase II clinical trial of a granulocyte-macrophage colony-stimulating factor-encoding, second-generation oncolytic herpesvirus in patients with unresectable metastatic melanoma. J Clin Oncol 2009; 27: 5763-5771.

113 Kaufman HL, Kim DW, DeRaffele G, Mitcham J, Coffin RS, Kim-Schulze S. Local and distant immunity induced by intralesional vaccination with an oncolytic herpes virus encoding GM-CSF in patients with stage Illc and IV melanoma. Ann Surg Oncol 2010; 17: 718-730.

114 Hu JCC, Coffin RS, Davis CJ, Graham NJ, Groves N, Guest PJ et al. A phase I study of OncoVEXGM-CSF, a second-generation oncolytic herpes simplex virus expressing granulocyte macrophage colony-stimulating factor. Clin Cancer Res 2006; 12: 6737-6747.

115 Hallahan DE, Mauceri HJ, Seung LP, Dunphy EJ, Wayne JD, Hanna NN et al. Spatial and temporal control of gene therapy using ionizing radiation. Nat Med 1995; 1: 786-791.

116 Seiwert TY, Darga T, Haraf D, Blair EA, Stenson K, Cohen EEW et al. A phase I dose escalation study of Ad GV.EGR.TNF.11D (TNFerade ${ }^{\mathrm{TM}}$ Biologic) with concurrent chemoradiotherapy in patients with recurrent head and neck cancer undergoing reirradiation. Ann Oncol 2013; 24: 769-776.

117 Shimizu S, Tsukada J, Sugimoto T, Kikkawa N, Sasaki K, Chazono H et al. Identification of a novel therapeutic target for head and neck squamous cell carcinomas: a role for the neurotensin-neurotensin receptor 1 oncogenic signaling pathway. Int J Cancer 2008; 123: 1816-1823.

118 Wang Y, Tao Z-Z, Chen S-M, Xiao B-K, Zhou X-H, Liu J-P. Application of combination of short hairpin RNA segments for silencing VEGF, TERT, and $\mathrm{BCl}-\mathrm{xl}$ expression in laryngeal squamous carcinoma. Cancer Biol Ther 2008; 7: 896-901.

119 Clayman GL, El-Naggar AK, Lippman SM, Henderson YC, Frederick M, Merritt JA et al. Adenovirus-mediated p53 gene transfer in patients with advanced recurrent head and neck squamous cell carcinoma. J Clin Oncol 1998; 16: 2221-2232.

120 Zhang SW, Xiao SW, Liu CQ, Sun Y, Su X, Li DM et al. [Treatment of head and neck squamous cell carcinoma by recombinant adenovirus-p53 combined with radiotherapy: a phase II clinical trial of 42 cases]. Zhonghua Yi Xue Za Zhi 2003; 83: $2023-2028$. 